\title{
ANALISIS STRATEGI PEMBANGUNAN DESA WISATA DI SENTRA PENGRAJIN KERIS
}

\author{
Agus Hardiyanto1, Ir. Irwan Soejanto,M.T. ${ }^{2}$, Intan Berlianty, S.T., M.T. ${ }^{2}$ \\ 1. Mahasiswa Jurusan Teknik Industri \\ 2. Dosen Jurusan Teknik Industri \\ Jurusan Teknik Industri Fakultas Teknik Industri \\ Universitas pembangunan Nasional "Veteran" Yogyakarta \\ Jl. Babarsari 2 Tambakbayan, Yogyakarta, 55281 \\ Telp. (0274) 485363 Fak : (0274) 486256 email : jur_tiupn@telkom.net
}

\begin{abstract}
ABSTRAK
Yogyakarta banyak memiliki potensi wisata baru, salah satunya adalah sentra pengrajin keris Banyumurup yang telah mengembangkan kerajinan tersebut sejak tahun 1950-an. Tujuan dari penelitian ini untuk mengetahui potensi wisata yang dimiliki Dusun Banyumurup dan merancang strategi pengembangan desa wisata.

Metode yang digunakan untuk mengetahui strategi pengembangan yaitu melalui analisis SWOT dengan cara menganalisis faktor-faktor eksternal (peluang dan ancaman) dan faktor-faktor internal (kekuatan dan kelemahan) dengan matriks EFAS dan IFAS. Matriks EFAS (External Factor Analysis Summary) digunakan untuk menganalisis faktor-faktor yang berupa peluang dan ancaman yang dihadapi. Matriks IFAS (Internal Factor Analysis Summary) digunakan untuk menganalisis faktor-faktor yang berupa kekuatan dan kelemahan yang dimiliki.

Berdasarkan hasil penelitian diketahui total nilai tertimbang matriks IFAS pengunjung sebesar 2,5073 . Total nilai tertimbang EFAS pengunjung sebesar 2,221. Faktor internal yang dimiliki yaitu suasana khas pedesaan, melihat proses pembuatan keris, pemandangan alam yang indah, keramahan masyarakat, terdapat bangunan bersejarah. Sedangakan faktor eksternal yaitu melestarikan budaya Jawa, meyerap tenaga kerja, pemanfaatan teknologi untuk media promosi, kesan positif dari wisatawan yang pernah berkunjung, perluasan segmen wisatawan dari berbagai minat seperti fotografi, pendidikan atau penelitian.
\end{abstract}

\section{Kata Kunci: Desa Wisata, Analisis SWOT, Dusun Banyumurup}

\section{ABSTRACT}

Yogyakarta has many new tourism potential, one of them is the center of Banyumurup keris craftsmen who have been developing the craft since the 1950's. The purpose of this research is to know the tourism potential owned by Dusun Banyumurup and to design the development strategy of tourist village.

The method used to know the development strategy is through SWOT analysis by analyzing the external factors (opportunities and threats) and internal factors (strengths and weaknesses) with EFAS and IFAS matrix. EFAS Matrix (External Factor Analysis Summary) is used to analyze the factors in the form of opportunities and threats encountered. IFAS Matrix (Internal Factor Analysis Summary) is used to analyze the factors in the form of strengths and weaknesses.

Based on the results of the research, the total weighted value of IFAS matrix of visitors is 2.5073. The total weighted EFAS value of visitors is 2,221. Internal factors that are owned is a typical rural atmosphere, see the process of making a keris, beautiful landscapes, community friendliness, there are historical buildings. While external factors are preserving Javanese culture, absorbing workforce, utilizing technology for promotion media, positive impression from tourists who have visited, expanding the segment of tourists from various interests such as photography, education or research.

\section{Keywords: Tourism Village, SWOT Analysis, Banyumurup Village}

\section{PENDAHULUAN}

Indonesia memiliki keanekaragaman kesenian dan budaya, banyaknya keanekaragaman membuat suatu daerah mempunyai ciri khasnya sendiri. Dan ciri khas yang dimiliki daerah tersebut dapat dijadikan sebagai tempat wisata unggulan yang menarik.Yogyakarta sebagai daerah pariwisata dan pusat kebudayaan Jawa memiliki potensi yang cukup besar dalam pengembangan industri pariwisata. Pariwisata layak dikembangkan terutama untuk mendorong kegiatan non pertanian yang diharapkan mampu memberikan pendapatan daerah.Dari beberapa potensi wisata di Yogyakarta salah satunya adalah sentra pengrajin keris Banyumurup yang terletak di sebelah tenggara Makam Raja-raja Imogiri tepatnya berada di wilayah Desa Girirejo, 
Kecamatan Imogiri, Kabupaten Bantul, Daerah Istimewa Yogyakarta. Dusun Banyumurup telah mengembangkan kerajinan tersebut sejak tahun 1950-an, dimana sentra kerajinan keris Banyusumurup merupakan sentra pengrajin yang memproduksi Keris kodian, warangka (rangka keris) dan pendok (gagang keris).Potensi wisata sentra pengrajin keris di Dusun Banyumurup sangat baik dalam industri pariwisata khususnya dalam rangka melestrikan budaya Jawa belum banyak dilirik oleh wisatawan. Untuk mengembangkan menjadi desa wisata dapat dilakukan dengan mengidentifikasi potensi dan masalah yang ada di Dusun Banyumurup. Halhal tersebut membutuhkan pertimbangan dari penilaian yang komprehensif terhadap potensi yang dimiliki. Selanjutnya perumusan strategi dilakukan dengan memanfaatkan analisis SWOT (Strengths, Opportunities, Weakness, Threats), yang hasilnya adalah dirumuskannya usulan strategi pengembangan berdasarkan strategi kekuatan dan peluang, strategi kelemahan dan peluang, strategi kekuatan dan ancaman, dan strategi kelemahan dan ancaman.Metode ini digunakan untuk mengetahui metode strategi pengembangan melalui analisis SWOT dengan cara menganalisis faktor-faktor eksternal (peluang dan ancaman) dan faktor-faktor internal (kekuatan dan kelemahan) dengan matriks EFAS dan IFAS.

\section{LANDASAN TEORI \\ 2.1 Definisi Pariwisata}

Menurut Spillane (1987), Pariwisata adalah perjalanan dari satu tempat ke tempat lain, bersifat sementara, dilakukan perorangan maupun kelompok, sebagai usaha mencari keseimbangan atau keserasian dan kebahagiaan dengan lingkungan hidup dalam dimensi sosial, budaya, alam, dan ilmu.

\subsubsection{Jenis-jenis Pariwisata}

Seseorang yang melakukan perjalanan wisata ke suatu daerah biasanya karena ingin sekedar untuk refreshing dan sekedar untuk berjalan-jalan. Selain itu, ada juga yang melakukan perjalanan wisata karena ada urusan bisnis ke suatu daerah. Ada berbagai jenis pariwisata yang dikelompokkan berdasarkan tujuan atau motif seseorang atau kelompok yang melakukan perjalanan wisata. Berikut jenis-jenis Pariwisata menurut Spillane (1987) :
1. Pariwisata untuk Menikmati Perjalanan (Pleasure Tourism)

Jenis pariwisata ini dilakukan oleh orangorang yang meninggalkan tempat tinggalnya untuk berlibur, untuk mencari udara segar yang baru, untuk memenuhi kehendak ingin tahunya, untuk mengendorkan ketegangan sarafnya, untuk melihat sesuatu yang baru, untuk menikmati keindahan alam, atau bahkan untuk mendapatkan ketenangan dan kedamaian di daerah luar kota.

2. Pariwisata untuk Rekreasi (Recreation Tourism)

Jenis pariwisata ini dilakukan oleh orangorang yang menghendaki pemanfaatan hari-hari liburnya untuk beristirahat, untuk memulihkan kembali kesegaran jasmani dan rohaninya, yang ingin menyegarkan keletihan dan kelelahannya.

3. Pariwisata untuk Kebudayaan (Cultural Tourism)

Jenis pariwisata ini dilakukan karena adanya keinginan untuk mempelajari adat istiadat, kelembagaan, dan cara hidup rakyat daerah lain, selain itu untuk mengunjungi monumen bersejarah, peninggalan peradaban masa lalu, pusat-pusat kesenian, pusat-pusat keagamaan, atau untuk ikut serta dalam festival-festival seni musik, teater, tarian rakyat dan lain-lain.

\subsubsection{Industri Pariwisata}

Menurut Oka A. Yoeti (2008), batasan pariwisata sebagai suatu industri diberikan secara terbatas, hanya sekedar untuk menggambarkan apa sebenarnya pariwisata itu. Istilah industri pariwisata lebih banyak bertujuan memberikan daya tarik supaya pariwisata dapat dianggap sebagai sesuatu yang berarti bagi perekonomian suatu negara. Sebagai suatu industri, pariwisata tidak dapat diukur, karena tidak memiliki standar nomor klasifikasi seperti dikatakan oleh Robert Christie Mill dan Alais M. Morison : "There is No Standard Industrial Classification Number for Tourism" (Oka A. Yoeti, 2008).

2.1.3 Penawaran Pariwisata

Menurut Spillane (1987), aspek-aspek penawaran pariwisata terdiri dari :

1. Proses produksi industry pariwisata.

2. Pentingnya Tenaga Kerja dan Penyediaannya.

3. Pentingnya Infrastruktur/Prasarana

4. Pentingnya Kredit

\subsubsection{Permintaan Pariwisata}

Menurut Spillane (1987), salah satu faktor yang sangat mempengaruhi permintaan 
adalah mobilitas. Mobilitas manusia timbul oleh berbagai macam dorongan kebutuhan/kepentingan yang disebut dengan istilah motivasi, yang dapat digolongkan sebagai berikut :

1. Dorongan kebutuhan dagang atau ekonomi.

2. Dorongan kebutuhan kepentingan politik.

3. Dorongan kebutuhan keamanan.

4. Dorongan kebutuhan kesehatan.

5. Dorongan kebutuhan pemukiman.

\subsection{Pengertian Analisis SWOT}

Menurut Freddy (1997), analisis SWOT adalah identifikasi berbagai faktor secara sistematif untuk merumuskan strategi perusahaan. Analisis ini didasarkan pada logika yang dapat memaksimalkan kekuatan (Strengths) dan peluang (Opportunities), namun secara bersamaan dapat meminimalkan kelemahan (Weaknesses) dan ancaman (Threats). Proses pengambilan keputusan strategis selalu berkaitan dengan pengembangan misi, tujuan, strategi, dan kebijakan perusahaan. Dengan demikian perencana strategis (strategy planner) harus menganalisis faktor-faktor strategis perusahaan (kekuatan, kelemahan, peluang dan ancaman) dalam kondisi yang ada saat ini.Rais (2009), metode analisa SWOT dianggap sebagai metode analisa yang paing dasar, berguna untuk melihat suatu topik atau permasalahan dari 4 (empat) sisi yang berbeda.

Hasil analisa biasanya adalah arahan atau rekomendasi untuk mempertahankan kekuatan dan menambah keuntungan dari peluang yang ada, sambil mengurangi kekurangan dan menghindari ancaman. Jika digunakan dengan benar, analisa SWOT akan membantu kita untuk melihat sisi-sisi yang terlupakan atau tidak terlihat selama ini. Analisa ini terbagi atas empat komponen dasar yaitu, Strengths adalah situasi atau kondisi yang merupakan kekuatan dari organisasi atau program pada saat ini, Weaknesses adalah situasi atau kondisi yang merupakan kelemahan dari organisasi atau program pada saat ini, Opportunities adalah situasi atau kondisi yang merupakan peluang di luar organisasi dan memberikan peluang berkembang bagi organisasi di masa depan, Threats adalah situasi yang merupakan ancaman bagi organisasi yang datang dari luar organisasi dan dapat mengancam eksistensi organisasi di masa depan.

\subsubsection{Manfaat Analisis SWOT}

Analisis SWOT dianggap memiliki banyak manfaat atau kelebihan dibandingkan dengan metode analisis lain. Berikut merupakan penjabaran beberapa manfaat menggunakan metode analisis SWOT :

1. Analisis SWOT dapat membantu melihat suatu persoalan dari empat sisi sekaligus yang menjadi dasar sebuah analisis persoalan, yaitu kekuatan, kelemahan, kesempatan/peluang, dan ancaman.

2. Analisis SWOT mampu memberikan hasil berupa analisis yang cukup tajam sehingga mampu memberikan arahan ataupun rekomendasi untuk mempertahankan kekuatan sekaligus menambah keuntungan berdasarkan sisi peluang yang ada, sambil mengurangi kekurangan dan juga menghindari ancaman.

3. Analisis SWOT dapat membantu kita "membedah" organisasi dari empat sisi yang dapat menjadi dasar dalam proses identifikasinya dan dengan analisis ini kita dapat menemukan sisi-sisi yang terkadang terlupakan atau tidak terlihat selama ini.

4. Analisis SWOT dapat menjadi instrumen yang cukup ampuh dalam melakukan analisis strategi, sehingga dapat menemukan langkah yang tepat dan terbaik sesuai dengan situasi pada saat itu.

\subsubsection{Unsur-unsur Matriks SWOT}

Adapun unsur-unsur matriks SWOT sebagai berikut :

1. Kekuatan dan kelemahan (Strengths and Weaknesses)

Kekuatan adalah suatu sumber, keterampilan atau keuntungankeuntungan lainnya dalam menghadapi para kompetitornya dan kebutuhan-kebutuhan pasar yang disajikan oleh suatu perusahaan. Kekuatan itu dapat hadir dalam wujud sumber-sumber keuangan, citra kepemimpinan pasar, hubungan pembeli-suplier, dan factor-faktor lainnya. 
Kelemahan merupakan keterbatasan atau defisiensi sumber, keterampilan atau kemampuan yang secara serius menghambat kinerja efektif perusahaan. Fasilitas, sumber keuangna, kemampuan modal, keterampilan pemasaran dan citra merk dapat menjadi sumber-sumber kelemahan (Mardalis, 2001).

2. Peluang dan Ancaman (Opportunities and Threats)

Peluang adalah suatu yang sangat baik dalam lingkungan perusahaan. Identifikasi pada suatu segmen pasar yang diabaikan, perubahan persaingan atau keadaan regulasi, perubahan teknologi dan hubungan dengan pembeli-supplier yang diperbaiki dapat menyajikan peluang bagi perusahaan

Ancaman adalah situasi yang buruk dalam lingkungan perusahaan. Ancaman merupakan hambatan atau rintangan penting terhadap posisi perusahaan sekarang atau posisi yang diinginkan. Masuknya kompetitor baru, pertumbuhan pasar yang lambat, perubahan teknologi dan regulasi baru atau direvisi, dapat menyajikan ancaman bagi keberhasilan perusahaan.

\subsubsection{Analisis Faktor Internal}

Setelah mendapatkan data-data dari faktor internal perusahaan selanjutnya dilakukan pembobotan Faktor penentu internal, dan kemudian dibuat suatu matriks IFAS (Internal Factor Analysis Summary).

Pembobotan bertujuan untuk mengkuantifikasi faktor-faktor internal yang telah dianalisis. Rentang atau skala nilai bobot yang digunakan adalah satu sampai lima. Aturan yang digunakan dalam pengisian kolom adalah :

1 : Sangat Tidak Penting (STP)

2 : Tidak Penting (TP)

3 : Cukup Penting (CP)

4 : Penting $(\mathrm{P})$

\section{5 : Sangat Penting (SP)}

Bobot setiap variabel diperoleh dengan menentukan nilai setiap variable

terhadap jumlah keseluruhan variabel dengan menggunakan rumus (Kinnear dan Taylor 1996, diacu dalam Syahroni). a_i $=$

(x i) $/\left(\sum\right.$

$\mathrm{Xi)}$. (2.1)

Keterangan :

a_i : bobot variable ke i

i : $1,2,3, \ldots, n$

$\mathrm{x} \_\mathrm{i}$ : nilai variable ke $\mathrm{i}$

$\mathrm{n}$ : jumlah variabel

\subsubsection{Analisis SWOT}

Langkah-langkah menyusun matriks SWOT adalah sebagai berikut :

1. Daftarkan setiap peluang eksternal perusahaan yang menentukan.

2. Daftarkan setiap ancaman eksternal perusahaan yang menentukan.

3. Daftarkan setiap kekuatan internal perusahaan yang menentukan.

4. Daftarkan setiap kelemahan internal perusahaan yang menentukan.

5. Mencocokkan kekuatan internal dengan peluang eksternal dan mencatat resultan strategi SO dalam sel yang ditentukan.

6. Mencocokkan kekuatan internal dengan ancaman eksternal dan mencatat resultan strategi ST dalam sel yang ditentukan.

7. Mencocokkan kelemahan internal dengan peluang eksternal dan mencatat resultan strategi WO dalam sel yang ditentukan.

8. Mencocokkan kelemahan internal dengan ancaman eksternal dan mencatat resultan strategi WT dalam sel yang ditentukan.

\section{METODOLOGI PENELITIAN 3.1 Objek Penelitian}

Penelitian ini dilakukan di sentra pengrajin keris Dusun Banyumurup, lebih tepatnya berada di Desa Girirejo, Kecamatan 
Imogiri, Kabupaten Bantul, Daerah Istimewa Yogyakarta.

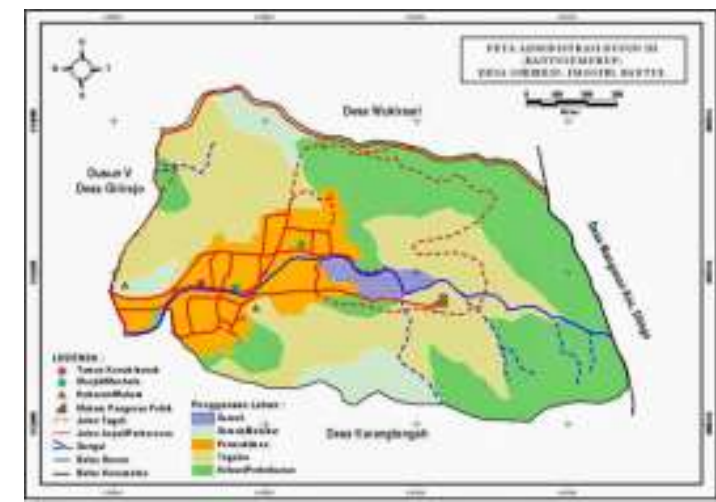

Gambar 3.1 Peta Administrasi Dusun III (Banyumurup)

\subsection{Pengumpulan Data}

Pada penelitian ini, pengumpulan data yang diperlukan menjadi dua jenis, yaitu data primer dan data sekunder.

\subsubsection{Data Primer}

Data yang diperlukan dalam penelitian ini berupa data primer yaitu data yang diperoleh langsung melalui pengamatan pada obyek. Metode yang dipakai untuk pengumpulan data primer adalah :

1. Observasi, yaitu metode pengumpulan data dengan cara pengamatan secara langsung terhadap obyek penelitian yaitu di Dusun Banyumurup serta dokumen yang berhubungan dengan masalah yang diteliti.

2. Wawancara, yaitu metode pengumpulan data dengan cara tanya jawab langsung kepada wisatawan dan perangkat desa di Dusun Banyumurup.

3. Kuesioner, yaitu metode pengumpulan data yang terdiri dari sekumpulan pertanyaan yang diberikan kepada responden guna memperoleh data tanggapan responden mengenai faktor strategi eksternal dan faktor strategi internal.

\subsubsection{Data Sekunder}

Sedangkan data sekunder merupakan data yang diperoleh dari studi literature seperti buku dan jurnal yang terkait materi dalam penelitian ini. Adapun data sekunder pada penelitian ini adalah :
1. Studi Pustaka Metode SWOT

Yang dijadikan acuan adalah langkah menentukan EFAS dan IFAS, skala penilaian rating dan gambar diagram analisis SWOT.

\subsection{Pengolahan Data}

Analisa dalam penelitian ini dapat dilakukan secara subyektif, yaitu mengamati objek secara langsung. Adapun metode SWOT ini terdiri dari tahapan yaitu :

1. Uji Validitas Kuesioner

Pada proses uji validitas kuesioner ini menggunakan bantuan software SPSS (Statistical Product and Service Solution). Validitas yang digunakan adalah korelasi product moment yaitu korelasi masing-masing butir pertanyaan pada kuesioner dengan skor total seluruh butir pertanyaan kuesioner. Setelah proses pearson correlation (r) untuk setiap butir pertanyaaan kemudian dibandingkan dengan tabel harga kritis dari $r$ Product Moment. Jika $r$ tabel $<r$ hitung maka butir pertanyaan dikatakan valid. Rumus yang digunakan dapat dilihat pada Persamaan 2.3.

2. Uji Reliabilitas Kuesioner

Pada proses uji reliabilitas merupakan pengujian untuk menunjukan kehandalan dari sebuah kuesioner. Semakin tinggi nilai kuesioner maka semakin dapat dipercaya pula data yang didapatkan. Nilai kuesioner berkisar dari 0,60 sampai 1,00 . Apabila nilai alpha cronbach mendekati nilai 1,00 maka dapat dikatakan data semakin reliabel. Pengujian dilakukan dengan menggunakan software SPSS. Rumus yang digunakan dapat dilihat pada Persamaan 2.4.

3. Perhitungan bobot faktor internal dan eksternal

Pembobotan bertujuan untuk mengkuantifikasi faktor-faktor internal 
yang telah dianalisis. Rentang atau skala nilai bobot yang digunakan adalah satu sampai lima. Aturan yang digunakan dalam pengisian kolom adalah :

1 : Sangat Tidak Penting (STP)

2 : Tidak Penting (TP)

3 : Cukup Penting (CP)

4 : Penting (P)

5 : Sangat Penting (SP)

Bobot setiap variabel diperoleh dengan menentukan nilai setiap variable

terhadap jumlah keseluruhan variabel dengan menggunakan rumus Persamaan 2.1 .

4. Matriks IFAS (Internal Factor Analysis Summary)

a. Menentukan faktor-faktor yang termasuk ke dalam kekuatan dan kelemahan suatu objek pada kolom 1 (Faktor Strategi Internal).

b. Memberikan bobot masingmasing dari faktor tersebut dari skala 1,0 (paling penting) sampai 0,0 (tidak penting). Jumlah dari semua bobot tersebut tidak boleh lebih dari 1,00 .

c. Menentukan rating untuk masingmasing faktor kekuatan dengan memberikan skala mulai dari 4 (sangat baik) sampai dengan 1 (sangat kurang) berdasarkan pengaruh faktor tersebut terhadap kondisi destinasi wisata yang bersangkutan. Sedangkan faktor kelemahan sebaliknya, pemberian skala dimulai dari 1 (kelemahan besar) sampai dengan 4 (kelemahan kecil).

d. Mengalikan bobot dengan rating untuk menentukan faktor yang nilainya bervariasi pada kolom 4 .

e. Menjumlahkan skor hasil perkalian dari bobot dengan rating untuk memperoleh total skor bagi objek yang bersangkutan. Nilai total tersebut menunjukan bagaimana suatu objek berreaksi terhadap faktor-faktor strategis internalnya. Total skor ini dapat digunakan sebagai pembanding antara objek tersebut dengan objek yang lain yang mempunyai konsep yang sama. Penyusunan table dapat dilihat pada Tabel 2.2.

5. Matriks EFAS (External Factor Analysis Summary)

a. Mengidentifikasi faktor eksternal dengan cara menuliskan peluang dan ancaman yang dihadapi. Sebaiknya faktor-faktor peluang didaftarkan terlebih dahulu, baru kemudian faktorfaktor ancaman.

b. Memberikan bobot pada setiap kekuatan dan kelemahan, dengan range 0 sampai 1 , total bobot yang diberikan kepada semua faktor baik itu peluang maupun ancaman harus sama dengan satu. Nilai bobot ini berasal dari perhitungan menggunakan metode paired comparison. Oleh karena itu besar kecilnya bobot masing-masing faktor bergantung kepada hasil yang diperoleh dari perhitungan menggunakan metode paired comparison.

c. Memberikan rating 1 sampai dengan 4 pada setiap peluang dan ancaman untuk mengindikasikan seberapa efektif perusahaan merespon peluang/ancaman yang bersangkutan. 4 (respon sangat superior), 3 (respon diatas rata-rata), 2 (respon rata-rata), 1 (respon jelek).

d. Mengalikan bobot dengan rating untuk mendapatkan nilai tertimbang.

e. Menjumlahkan nilai tertimbang untuk mendapatkan total nilai tertimbang. Nilai total ini akan berkisar antara 1 sampai dengan 4. Nilai 1 menunjukan bahwa dalam strategi organisasi tidak memanfaatkan peluang atau tidak menghindari ancaman eksternal. Nilai 4 menunjukkan bahwa organisasi merespon dengan sangat baik terhadap 
peluang dan ancaman yang ada dalam industrinya. Nilai 2,5 menunjukkan sistem mampu merespon situasi eksternal secara rata-rata.

\section{PENGOLAHAN DATA DAN ANALISIS HASIL}

\subsection{Pengumpulan Data}

Berdasarkan hasil pengamatan dan wawancara terhadap warga dan Kepala Dusun Banyumurup sebagai pihak yang mengetahui kekuatan dan kelemahan yang dapat dikembangkan sebagai desa wisata. Disamping juga memiliki faktor eksternal yang terdiri dari peluang dan ancaman yang perlu mendapat perhatian khusus.

4.1.1 Identifikasi potensi lingkungan internal

Berdasarkan hasil identifikasi faktor internal di Dusun Banyumurup yang termasuk dalam kekuatan meliputi letak yang strategis, sentra kerajinan keris, pemandangan alam yang indah, keramahan masyarakat, terdapat bangunan bersejarah.

Unsur lain yang terdapat pada faktor internal adalah kelemahan meliputi pengrajin keris yang makin berkurang, kurangnya partisipasi masyarakat, promosi belum maksimal, kurang maksimalnya toko souvenir, kurangnya tenaga kerja profesional dalam pengelolaan obyek wisata.

4.1.2 Identifikasi potensi lingkungan eksternal

Faktor eksternal yang berpengaruh pada pengembangan desa wisata di Dusun Banyumurup yang termasuk dalam peluang meliputi, melestarikan budaya Jawa, menyerap tenaga kerja, pemanfaatan teknologi untuk media promosi, kesan positif dari wisatawan yang pernah berkunjung, perluas segmen wisatawan dari berbagai minat seperti fotografi, pendidikan atau penelitian.

Unsur lain yang terdapat pada faktor eksternal adalah ancaman meliputi, penawaran desa wisata ditempat lain, kurangnya alat transportasi umum., kurangnya dukungan dari Pemerintah Daerah, minimnya petunjuk arah menuju lokasi, terjadinya bencana / gangguan alam.

\subsubsection{Penentuan Bobot dan Rating}

Penilaian faktor eksternal dan faktor internal berdasarkan pengaruh faktor tersebut terhadap posisi strategis Dusun Banyumurup. Jurusan Teknik Industri Fakultas Teknik UPN "Veteran" Yogyakarta
Penilaian bobot ini didapatkan dari hasil kuesioner yang diberikan kepada pihak responden yaitu 45 orang dengan rincian 35 orang pengunjung dan 10 orang key/orang yang mengerti kondisi di Dusun Banyumurup.

Skala penilaian untuk factor eksternal dan factor internal adalah sebagai berikut.

$1:$ Sangat Tidak Penting (STP)

2: Tidak Penting (TP)

3 : Cukup Penting $(\mathrm{CP})$

4 : Penting $(\mathrm{P})$

5 : Sangat Penting (SP)

\subsubsection{Uji validitas}

Pengumpulan data dilakukan dengan melakukan penyebaran kuesioner kepada pengunjung dan perangkat desa di Dusun Banyumurup. Untuk jumlah sampel 45 , nilai $r$ table sebesar 0,294. Suatu item pertanyaan dinyatakan valid jika $r$ hitung $>r$ table. Hasil perhitungan dengan SPSS menunjukan bahwa semua pertanyaan dinyatakan valid dengan semua $r$ hitungan lebih besar dari pada 0,294.

Tabel 4.5 Hasil uji validitas

\begin{tabular}{|c|c|c|}
\hline \multicolumn{3}{|c|}{$\mathrm{r}=0,294$} \\
\hline Atribut & Corrected item (r hitung) & Keterangan \\
\hline S1 & 0.490 & Valid \\
\hline S2 & 0.624 & Valid \\
\hline S3 & 0.310 & Valid \\
\hline S4 & 0.352 & Valid \\
\hline S5 & 0.590 & Valid \\
\hline W1 & 0.622 & Valid \\
\hline W2 & 0.616 & Valid \\
\hline W3 & 0.340 & Valid \\
\hline W4 & 0.640 & Valid \\
\hline W5 & 0.435 & Valid \\
\hline O1 & 0.473 & Valid \\
\hline O2 & 0.646 & Valid \\
\hline O3 & 0.503 & Valid \\
\hline O4 & 0.294 & Valid \\
\hline O5 & 0.328 & Valid \\
\hline T1 & 0.473 & Valid \\
\hline T2 & 0.462 & Valid \\
\hline T3 & 0.544 & Valid \\
\hline T4 & 0.399 & \\
\hline T5 & 0.475 & \\
\hline
\end{tabular}

Reliabilitas instrument adalah hasil pengukuran yang dapat dipercaya. Reliabilitas 
instrument diperlukan untuk mendapatkan data sesuai dengan tujuan pengukuran (Sujianto A.E, 2009). Setelah dilakukan uji validitas kemudian dilakukan pengujian reliabilitas dengan menggunakan sofware SPSS. Hasil uji reliabilits, diperoleh nilai Cronbach's Alpha if Item Delected sebesar 0.877, lebih besar dari 0,60 sehingga data dikatakan reliabel.

Tabel 4.6 Hasil uji reliabilitas

\begin{tabular}{|c|c|c|}
\hline & $\begin{array}{c}\boldsymbol{\alpha} \\
\text { tetapan } \\
\mathbf{= 0 , 6}\end{array}$ & Keterangan \\
\hline $\begin{array}{c}\text { Alpha } \\
\text { Croncback }\end{array}$ & 0,877 & realiable \\
\hline
\end{tabular}

\subsection{Pengolahan Data}

\subsubsection{Deskripsi Objek Penelitian}

Dusun Banyumurup terletak diwilayah Kabupaten Bantul, berjarak kurang lebih 17 km dari pusat Kota Yogyakarta. Sejak tahun 1950-an Dusun Banyumurup sudah berkembang menjadi sentra pengrajin keris, dimana pengunjung dapat melihat proses pembuatan keris secara langsung. Wilayah ini bisa dijangkau dengan berjalan lurus keselatan dari perempatan Terminal Giwangan dan kemudian mengambil lajur kanan setelah sampai dipertigaan menuju makam Imogiri. Menuju Dusun Banyumurup dapat ditempuh dengan kendaraan pribadi atau taksi, sebab tak ada angkutan umum seperti bis yang melewati Dusun Banyumurup. Suasana sejuk khas pedesaan akan menyapa pengunjung setibanya dilokasi.

\subsubsection{Perhitungan bobot faktor internal}

Perhitungan dilakukan dengan cara membagi nilai angka pada setiap faktor dengan jumlah total nilai angka dari semua faktor yang ada. Berikut ini adalah contoh perhitungan bobot pada faktor internal.

Faktor letak yang strategis memiliki nilai 138. Perhitungan bobot untuk faktor ini adalah $\frac{138}{1376}=0,100$. Perhitungan bobot untuk faktor lainnya dapat dilihat pada lampiran 2 .

Tabel 4.7 Perhitungan bobot faktor internal pengunjung

\begin{tabular}{|c|c|c|c|c|c|c|c|c|}
\hline $\begin{array}{l}\mathrm{N} \\
\mathrm{o}\end{array}$ & $\begin{array}{l}\text { Kekuatan } \\
\text { (Strengths) }\end{array}$ & 5 & 4 & 3 & 2 & 1 & $\begin{array}{l}\text { Pengolaha } \\
\text { n Data } \\
\text { Kuesioner }\end{array}$ & $\begin{array}{c}\text { Bobo } \\
t\end{array}$ \\
\hline S1 & $\begin{array}{ll}\begin{array}{l}\text { Letak } \\
\text { strategis }\end{array} & \text { yang } \\
\end{array}$ & $\begin{array}{l}1 \\
0\end{array}$ & $\begin{array}{l}1 \\
7 \\
\end{array}$ & 5 & 2 & 1 & 138 & 0,100 \\
\hline S2 & $\begin{array}{l}\text { Sentra kerajinan } \\
\text { keris }\end{array}$ & $\begin{array}{l}1 \\
3 \\
\end{array}$ & 8 & $\begin{array}{l}1 \\
1 \\
\end{array}$ & 3 & 0 & 136 & 0,099 \\
\hline S3 & $\begin{array}{l}\text { Pemandangan } \\
\text { alam }\end{array}$ & $\begin{array}{l}1 \\
1 \\
\end{array}$ & $\begin{array}{l}1 \\
5 \\
\end{array}$ & 6 & 2 & 1 & 138 & 0,100 \\
\hline S4 & $\begin{array}{l}\text { Keramahan } \\
\text { masyarakat }\end{array}$ & $\begin{array}{l}1 \\
2 \\
\end{array}$ & $\begin{array}{l}1 \\
6 \\
\end{array}$ & 5 & 5 & 2 & 151 & 0,110 \\
\hline
\end{tabular}

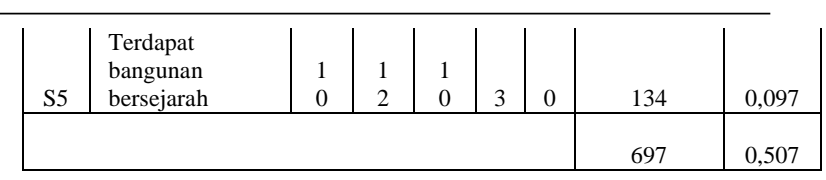

\begin{tabular}{|c|c|c|c|c|c|c|c|c|}
\hline No & $\begin{array}{l}\text { Kelemahan } \\
\text { (Weaknesses) }\end{array}$ & 5 & 4 & 3 & 2 & 1 & $\begin{array}{l}\text { Pengolaha } \\
\text { n Data } \\
\text { Kuesioner }\end{array}$ & $\begin{array}{c}\text { Bobo } \\
t\end{array}$ \\
\hline $\begin{array}{l}\text { W } \\
1\end{array}$ & $\begin{array}{l}\text { Pengrajin keris } \\
\text { yang makin } \\
\text { berkurang }\end{array}$ & $\begin{array}{l}1 \\
1\end{array}$ & $\begin{array}{l}1 \\
2\end{array}$ & $\begin{array}{l}1 \\
0\end{array}$ & 2 & 0 & 137 & 0,100 \\
\hline $\begin{array}{l}\text { W } \\
2\end{array}$ & $\begin{array}{l}\text { Kurangnya } \\
\text { partisipasi } \\
\text { masyarakat }\end{array}$ & $\begin{array}{l}1 \\
0\end{array}$ & $\begin{array}{l}1 \\
4\end{array}$ & 8 & 3 & 0 & 136 & 0,099 \\
\hline $\begin{array}{l}W \\
3 \\
\end{array}$ & $\begin{array}{l}\text { Promosi belum } \\
\text { maksimal }\end{array}$ & 8 & $\begin{array}{l}1 \\
4 \\
\end{array}$ & $\begin{array}{l}1 \\
1\end{array}$ & 2 & 0 & 133 & 0,097 \\
\hline $\begin{array}{l}\text { W } \\
4\end{array}$ & $\begin{array}{l}\text { Kurang } \\
\text { maksimalnya } \\
\text { toko souvenir }\end{array}$ & 9 & $\begin{array}{l}1 \\
1\end{array}$ & $\begin{array}{l}1 \\
2\end{array}$ & 3 & 0 & 131 & 0,095 \\
\hline $\begin{array}{l}W \\
5\end{array}$ & $\begin{array}{l}\text { Kurannya } \\
\text { tenaga kerja } \\
\text { profesional } \\
\text { dalam } \\
\text { pengelolaan } \\
\text { obyek wisata }\end{array}$ & $\begin{array}{l}1 \\
2\end{array}$ & $\begin{array}{l}1 \\
6\end{array}$ & 5 & 1 & 1 & 142 & 0,103 \\
\hline & & & & & & & 679 & 0,493 \\
\hline & Total & & & & & & 1376 & 1,000 \\
\hline
\end{tabular}

Tabel 4.8 Perhitungan bobot faktor internal Key person

\begin{tabular}{|c|c|c|c|c|c|c|c|c|}
\hline No & Kekuatan (Strengths) & 5 & 4 & 3 & 2 & 1 & $\begin{array}{c}\text { Pengolahan } \\
\text { Data Kuesioner }\end{array}$ & Bobo \\
\hline S1 & Letak yang strategis & 5 & 4 & 1 & 0 & 0 & 44 & 0,117 \\
\hline S2 & Sentra kerajinan keris & 2 & 3 & 4 & 1 & 0 & 36 & 0,095 \\
\hline S3 & Pemandangan alam & 5 & 4 & 1 & 0 & 0 & 44 & 0,117 \\
\hline S4 & $\begin{array}{l}\text { Keramahan } \\
\text { masyarakat }\end{array}$ & 2 & 4 & 3 & 1 & 0 & 37 & 0,098 \\
\hline S5 & $\begin{array}{l}\text { Terdapat bangunan } \\
\text { bersejarah }\end{array}$ & 2 & 2 & 5 & 1 & 0 & 35 & 0,093 \\
\hline & & & & & & & 196 & 0,520 \\
\hline No & $\begin{array}{c}\text { Kelemahan } \\
\text { (Weaknesses) }\end{array}$ & 5 & 4 & 3 & 2 & 1 & $\begin{array}{c}\text { Pengolahan } \\
\text { Data Kuesioner } \\
\end{array}$ & Bobo \\
\hline W1 & $\begin{array}{l}\text { Pengrajin keris yang } \\
\text { makin berkurang }\end{array}$ & 2 & 3 & 4 & 1 & 0 & 36 & 0,095 \\
\hline $\mathrm{W} 2$ & $\begin{array}{l}\text { Kurangnya partisipasi } \\
\text { masyarakat }\end{array}$ & 2 & 3 & 4 & 1 & 0 & 36 & 0,095 \\
\hline W3 & $\begin{array}{l}\text { Promosi belum } \\
\text { maksimal }\end{array}$ & 1 & 4 & 5 & 0 & 0 & 36 & 0,095 \\
\hline W4 & $\begin{array}{l}\text { Kurang maksimalnya } \\
\text { toko souvenir }\end{array}$ & 2 & 3 & 4 & 1 & 0 & 36 & 0,095 \\
\hline W5 & $\begin{array}{l}\text { Kurannya tenaga } \\
\text { kerja profesional } \\
\text { dalam pengelolaan } \\
\text { obyek wisata }\end{array}$ & 2 & 4 & 3 & 1 & 0 & 37 & 0,098 \\
\hline & & & & & & & 181 & 0,480 \\
\hline & Total & & & & & & 377 & 1,000 \\
\hline
\end{tabular}

\subsubsection{Perhitungan bobot faktor eksternal}

Tabel 4.9 Perhitungan bobot faktor eksternal pengunjung

\begin{tabular}{|c|l|c|c|c|c|c|c|c|}
\hline No & $\begin{array}{c}\text { Peluang } \\
\text { (Opportunities) }\end{array}$ & 5 & 4 & 3 & 2 & 1 & $\begin{array}{c}\text { Pengolahan } \\
\text { Data } \\
\text { Kuesioner }\end{array}$ & Bobot \\
\hline O1 & $\begin{array}{l}\text { Melestarikan } \\
\text { budaya jawa }\end{array}$ & 12 & 17 & 5 & 1 & 0 & 145 & 0,105 \\
\hline O2 & $\begin{array}{l}\text { Menyerap tenaga } \\
\text { kerja }\end{array}$ & 11 & 10 & 10 & 3 & 1 & 132 & 0,096 \\
\hline O3 & $\begin{array}{l}\text { Pemanfaatan } \\
\text { teknologi untuk } \\
\text { media promosi }\end{array}$ & 12 & 15 & 8 & 0 & 0 & 144 & 0,105 \\
\hline O4 & $\begin{array}{l}\text { Kesan positif dari } \\
\text { wisatawan yang } \\
\text { pernah berkunjung }\end{array}$ & 8 & 16 & 7 & 3 & 1 & 132 & 0,096 \\
\hline
\end{tabular}




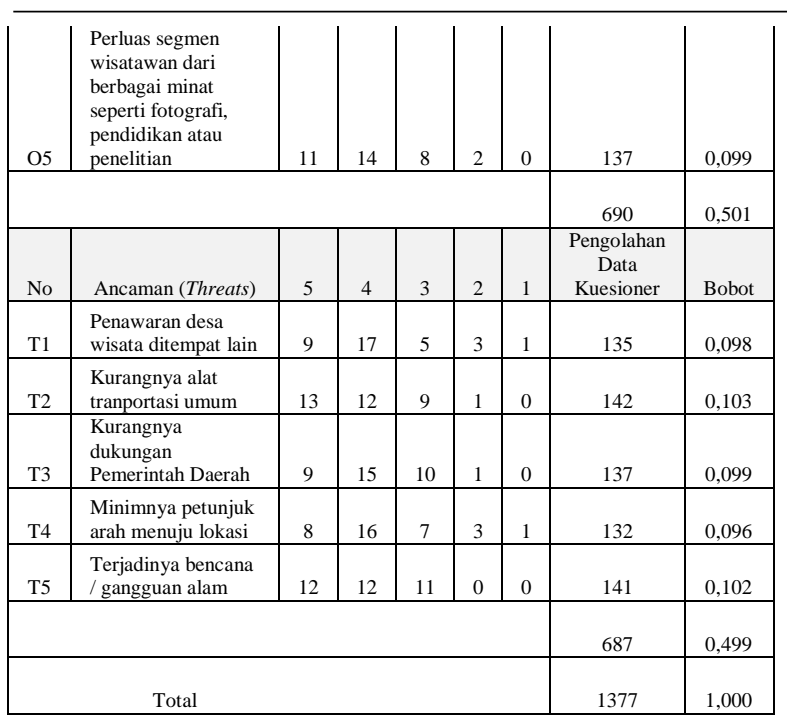

Tabel 4.10 Perhitungan bobot faktor eksternal key person

\begin{tabular}{|c|c|c|c|c|c|c|c|c|}
\hline No & Peluang (Opportunities) & 5 & 4 & 3 & 2 & 1 & $\begin{array}{c}\text { Pengolahan } \\
\text { Data } \\
\text { Kuesioner }\end{array}$ & Bobot \\
\hline 01 & $\begin{array}{l}\text { Melestarikan budaya } \\
\text { jawa }\end{array}$ & 2 & 4 & 3 & 1 & 0 & 35 & 0,088 \\
\hline $\mathrm{O} 2$ & Menyerap tenaga kerja & 2 & 3 & 4 & 1 & 0 & 36 & 0,091 \\
\hline $\mathrm{O} 3$ & $\begin{array}{l}\text { Pemanfaatan teknologi } \\
\text { untuk media promosi }\end{array}$ & 4 & 4 & 2 & 0 & 0 & 42 & 0,106 \\
\hline $\mathrm{O} 4$ & $\begin{array}{l}\text { Kesan positif dari } \\
\text { wisatawan yang pernah } \\
\text { berkunjung }\end{array}$ & 2 & 3 & 4 & 1 & 0 & 36 & 0,091 \\
\hline $\mathrm{O} 5$ & $\begin{array}{l}\text { Perluas segmen } \\
\text { wisatawan dari berbagai } \\
\text { minat seperti fotografi, } \\
\text { pendidikan atau } \\
\text { penelitian }\end{array}$ & 4 & 4 & 2 & 0 & 0 & 42 & 0,106 \\
\hline & & & & & & & 191 & 0,481 \\
\hline
\end{tabular}

Tabel 4.8 Perhitungan bobot faktor eksternal key person (lanjutan)

\begin{tabular}{|c|c|c|c|c|c|c|c|c|}
\hline No & Ancaman (Threats) & 5 & 4 & 3 & 2 & 1 & $\begin{array}{c}\text { Pengolahan } \\
\text { Data } \\
\text { Kuesioner }\end{array}$ & Bobot \\
\hline $\mathrm{T} 1$ & $\begin{array}{l}\text { Penawaran desa } \\
\text { wisata ditempat lain }\end{array}$ & 5 & 4 & 1 & 0 & 0 & 41 & 0,103 \\
\hline $\mathrm{T} 2$ & $\begin{array}{l}\text { Kurangnya alat } \\
\text { tranportasi umum }\end{array}$ & 4 & 4 & 2 & 0 & 0 & 42 & 0,106 \\
\hline $\mathrm{T} 3$ & $\begin{array}{l}\text { Kurangnya dukungan } \\
\text { Pemerintah Daerah }\end{array}$ & 4 & 4 & 2 & 0 & 0 & 42 & 0,106 \\
\hline $\mathrm{T} 4$ & $\begin{array}{l}\text { Minimnya petunjuk } \\
\text { arah menuju lokasi }\end{array}$ & 3 & 3 & 4 & 0 & 0 & 39 & 0,098 \\
\hline $\mathrm{T} 5$ & $\begin{array}{l}\text { Terjadinya bencana / } \\
\text { gangguan alam }\end{array}$ & 4 & 4 & 2 & 0 & 0 & 42 & 0,106 \\
\hline & & & & & & & 206 & 0,519 \\
\hline & Total & & & & & & 397 & 1,000 \\
\hline
\end{tabular}

\subsubsection{Matriks IFAS (Internal Factor Analysis Summary)}

Berikut hasil perhitungan matriks IFAS

(Internal Factor AnalysisSummary) pengunjung dan key person.

Contoh perhitungan skor

Skor $\mathrm{S} 1=$ bobot $\mathrm{x}$ rating

$$
=0,100 \times 2
$$

$$
=0,2006
$$

Hasil perhitungan lainnya dapat dilihat pada lampiran 2.

Tabel 4.11 Matriks IFAS (Internal Factor Analysis Summary) pengunjung

\begin{tabular}{|l|l|c|c|c|}
\hline \multicolumn{5}{|c|}{ Faktor-Faktor Strategi Internal (Internal Factor Analysis Summary) } \\
\hline No & \multicolumn{1}{|c|}{ Kekuatan (Strengths) } & Bobot & Rating & $\begin{array}{c}\text { Skor } \\
\text { (Bobot x } \\
\text { Rating) }\end{array}$ \\
\hline S1 & Letak yang strategis & 0,100 & 2 & 0,2006 \\
\hline S2 & Sentra kerajinan keris & 0,099 & 4 & 0,3953 \\
\hline S3 & Pemandangan alam yang indah & 0,100 & 3 & 0,3009 \\
\hline S4 & Keramahan masyarakat & 0,110 & 3 & 0,3292 \\
\hline S5 & Terdapat bangunan bersejarah & 0,097 & 3 & 0,2922 \\
\hline
\end{tabular}

Tabel 4.11 Matriks IFAS pengunjung (lanjutan)

\begin{tabular}{|l|l|c|c|c|}
\hline No & Kelemahan (Weakness) & Bobot & Rating & $\begin{array}{c}\text { Skor } \\
\text { (Bobot x Rating) }\end{array}$ \\
\hline W1 & $\begin{array}{l}\text { Pengrajin keris semakin } \\
\text { berkurang }\end{array}$ & 0,100 & 2 & 0,1991 \\
\hline W2 & $\begin{array}{l}\text { Kurangnya partisipasi } \\
\text { masyarakat }\end{array}$ & 0,099 & 3 & 0,2965 \\
\hline W3 & $\begin{array}{l}\text { Promosi belum } \\
\text { maksimal }\end{array}$ & 0,097 & 1 & 0,0967 \\
\hline W4 & $\begin{array}{l}\text { Kurang maksimalnya } \\
\text { toko souvenir }\end{array}$ & 0,095 & 2 & 0,1904 \\
\hline W5 & $\begin{array}{l}\text { Kurangnya tenaga } \\
\text { kerja professional } \\
\text { dalam pengelolaan } \\
\text { objek wisata }\end{array}$ & 0,103 & 2 & \\
\hline \multicolumn{1}{|c|}{ Total } & 1,000 & & 2,5073 \\
\hline
\end{tabular}

Berdasarkan hasil perhitungan matriks IFAS pengunjung dapat disimpulkan bahwa pihak Dusun Banyumurup, secara internal dapat dikatakan dalam kondisi rata-rata. Hal ini dapat dilihat dari nilai total skor yaitu sebesar 2,5073.

Pada table diatas dapat dilihat bahwa kekuatan utama Dusun Banyumurup adalah terdapatnya sentra pengrajin keris dengan skor sebesar 0,3953. Dengan adanya sentra pengrajin keris satu-satunya di Yogyakarta, dimana pengunjung dapat melihat proses pembuatan dan membeli langsung hasil dari pengrajin menjadi daya tarik utama yang ditawarkan Dusun Banyumurup.

Faktor kedua yaitu keramahan masyarakat dengan skor sebesar (0,3292), masyarakat merupakan bagian dari wisata dimana keramahan masyarakat pedesaan akan menimbulkan kesan positif dari tempat wisata tersebut. Faktor ketiga adalah pemandangan yang indah dengan skor $(0,3009)$, kontur wilayah yang berbukit-bukit dan terdapat air terjun menjadi salah satu kekuatan dalam menarik minat pengunjung. 
ISSN 1693-2102

OPSI - Jurnal Optimasi Sistem Industri

Faktor keempat yaitu terdapat bangunan bersejarah dengan skor $(0,2922)$, salah satu bangunan bersejara adalah Masjid Keraton Banyumurup yang sudah berusia ratusan tahun, dengan bangunan utama berbentuk joglo dan bagian serambi berbentuk limasan. Selanjutnya adalah Makam Banyumurup, Makam Banyusumurup merupakan Makam Pangeran Pekik, yang mana pangeran Pekik adalah putra pemimpin Surabaya yang ditaklukkan Sultan Agung tahun 1625. Faktor kelima yaitu letak yang strategis dengan skor $(0,2006)$, letak Dusun Banyumurup yang tidak terlalu jauh dari pusat Yogyakarta dan ditunjang dengan pembangunan jalan raya yang baik.

Kelemahan utama Dusun Banyumurup adalah promosi yang belum maksimal dengan nilai skor 0,0967. Kelemahan kedua adalah kurang maksimalnya toko souvenir dengan skor 0,1904 . Kelemahan ketiga adalah pengrajin keris yang semakin berkurang dengan skor 0,1991. Kelemahan keempat adalah Kurangnya tenaga kerja professional dalam pengelolaan objek wisata dengan skor 0,1977. Kelemahan kelima adalah kurangnya partisipasi masyarakat dengan skor 0,2965 .

Tabel 4.12 Matriks IFAS (Internal

Factor Analysis Summary) key person

\begin{tabular}{|c|c|c|c|c|}
\hline \multicolumn{5}{|c|}{ Faktor-Faktor Strategi Internal (Internal Factor Analysis Summary) } \\
\hline No & Kekuatan (Strengths) & Bobot & Rating & $\begin{array}{c}\text { Skor } \\
\text { (Bobot } x \text { Rating) }\end{array}$ \\
\hline S1 & Letak yang strategis & 0,117 & 2 & 0,233 \\
\hline S2 & $\begin{array}{l}\text { Sentra kerajinan } \\
\text { keris }\end{array}$ & 0,095 & 4 & 0,382 \\
\hline S3 & $\begin{array}{l}\text { Pemandangan alam } \\
\text { yang indah }\end{array}$ & 0,117 & 3 & 0,350 \\
\hline S4 & $\begin{array}{l}\text { Keramahan } \\
\text { masyarakat }\end{array}$ & 0,098 & 3 & 0,294 \\
\hline S5 & $\begin{array}{l}\text { Terdapat bangunan } \\
\text { bersejarah }\end{array}$ & 0,093 & 3 & 0,279 \\
\hline No & $\begin{array}{l}\text { Kelemahan } \\
\text { (Weakness) }\end{array}$ & Bobot & Rating & $\begin{array}{c}\text { Skor } \\
\text { (Bobot x Rating) }\end{array}$ \\
\hline W1 & $\begin{array}{l}\text { Pengrajin keris } \\
\text { semakin berkurang }\end{array}$ & 0,095 & 2 & 0,191 \\
\hline $\mathrm{W} 2$ & $\begin{array}{l}\text { Kurangnya } \\
\text { partisipasi } \\
\text { masyarakat }\end{array}$ & 0,095 & 3 & 0,286 \\
\hline W3 & $\begin{array}{l}\text { Promosi belum } \\
\text { maksimal }\end{array}$ & 0,095 & 1 & 0,095 \\
\hline W4 & $\begin{array}{l}\text { Kurang maksimalnya } \\
\text { toko souvenir }\end{array}$ & 0,095 & 2 & 0,191 \\
\hline W5 & $\begin{array}{l}\text { Kurangnya tenaga } \\
\text { kerja professional } \\
\text { dalam pengelolaan } \\
\text { objek wisata }\end{array}$ & 0,098 & 2 & 0,196 \\
\hline & Total & 1,000 & & 2,499 \\
\hline
\end{tabular}

Total nilai tertimbang Matriks IFAS Key Person adalah 2,499. Nilai ini menunjukkan bahwa posisi internal Dusun Banyumurup yang kuat.

\subsubsection{Matriks EFAS (External Factor Analysis Summary) \\ Berikut hasil perhitungan matriks EFAS} (External Factor Analysis Summary) pengunjung dan key person.

Tabel 4.13 Matriks EFAS (External Factor Analysis Summary) Pengunjung

\begin{tabular}{|c|c|c|c|c|}
\hline \multicolumn{5}{|c|}{ Faktor-Faktor Strategi Internal (Internal Factor Analysis Summary) } \\
\hline No & $\begin{array}{c}\text { Peluang } \\
\text { (Opportunities) }\end{array}$ & Bobot & Rating & $\begin{array}{c}\text { Skor } \\
\text { (Bobot x Rating) }\end{array}$ \\
\hline O1 & $\begin{array}{l}\text { Melestarikan } \\
\text { budaya jawa }\end{array}$ & 0,105 & 4 & 0,421 \\
\hline $\mathrm{O} 2$ & $\begin{array}{l}\text { Menyerap tenaga } \\
\text { kerja }\end{array}$ & 0,096 & 2 & 0,192 \\
\hline $\mathrm{O} 3$ & $\begin{array}{l}\text { Pemanfaatan } \\
\text { teknologi untuk } \\
\text { media promosi }\end{array}$ & 0,105 & 3 & 0,314 \\
\hline $\mathrm{O} 4$ & $\begin{array}{l}\text { Kesan positif dari } \\
\text { wisatawan yang } \\
\text { pernah berkunjung }\end{array}$ & 0,096 & 2 & 0,192 \\
\hline $\mathrm{O} 5$ & $\begin{array}{l}\text { Perluas segmen } \\
\text { wisatawan dari } \\
\text { berbagai minat } \\
\text { seperti fotografi, } \\
\text { pendidikan dan } \\
\text { penelitian } \\
\end{array}$ & 0,099 & 1 & 0,099 \\
\hline No & Ancaman (Threats) & Bobot & Rating & $\begin{array}{c}\text { Skor } \\
\text { (Bobot x Rating) }\end{array}$ \\
\hline T1 & $\begin{array}{l}\text { Penawaran desa } \\
\text { wisata ditempat } \\
\text { lain }\end{array}$ & 0,098 & 1 & 0,098 \\
\hline T2 & $\begin{array}{l}\text { Kurangnya alat } \\
\text { tranportasi umum }\end{array}$ & 0,103 & 3 & 0,309 \\
\hline T3 & $\begin{array}{l}\text { Kurangnya } \\
\text { dukungan } \\
\text { Pemerintah Daerah }\end{array}$ & 0,099 & 2 & 0,199 \\
\hline T4 & $\begin{array}{l}\text { Minimnya petunjuk } \\
\text { arah menuju lokasi }\end{array}$ & 0,096 & 2 & 0,192 \\
\hline T5 & $\begin{array}{l}\text { Terjadi } \\
\text { bencana/gangguan } \\
\text { alam }\end{array}$ & 0,102 & 2 & 0,205 \\
\hline & Total & 1,000 & & 2,221 \\
\hline
\end{tabular}

Berdasarkan matriks EFAS pengunjung di atas, total nilai tertimbangnya adalah 2,221. Hal ini menunjukkan bahwa Dusun Banyumurup merespons dengan cukup baik terhadap faktorfaktor eksternalnya yaitu objek wisata ini cukup baik dalam memanfaatkan peluang serta menghindari ancaman yang ada.

Tabel 4.14 Matriks EFAS (External

Factor Analysis Summary) key person

\begin{tabular}{|c|l|c|c|c|}
\hline \multicolumn{5}{|c|}{ Faktor-Faktor Strategi Internal (Internal Factor Analysis Summary) } \\
\hline No & Peluang (Opportunities) & Bobot & Rating & $\begin{array}{c}\text { Skor } \\
\text { (Bobot x Rating) }\end{array}$ \\
\hline O1 & $\begin{array}{l}\text { Melestarikan budaya } \\
\text { jawa }\end{array}$ & 0,088 & 4 & 0,353 \\
\hline O2 & Menyerap tenaga kerja & 0,091 & 2 & 0,181 \\
\hline O3 & $\begin{array}{l}\text { Pemanfaatan teknologi } \\
\text { untuk media promosi }\end{array}$ & 0,106 & 3 & 0,317 \\
\hline O4 & $\begin{array}{l}\text { Kesan positif dari } \\
\text { wisatawan yang pernah } \\
\text { berkunjung }\end{array}$ & 0,091 & 2 & 0,181 \\
\hline
\end{tabular}




\begin{tabular}{|c|l|c|c|c|}
\hline O5 & $\begin{array}{l}\text { Perluas segmen } \\
\text { wisatawan dari berbagai } \\
\text { minat seperti fotografi, } \\
\text { pendidikan dan } \\
\text { penelitian }\end{array}$ & 0,106 & 1 & 0,106 \\
\hline No & $\begin{array}{c}\text { Ancaman (Threats) } \\
\text { Bobot }\end{array}$ & Rating & $\begin{array}{c}\text { Skor } \\
\text { (Bobot x Rating) }\end{array}$ \\
\hline T1 & $\begin{array}{l}\text { Penawaran desa wisata } \\
\text { ditempat lain }\end{array}$ & 0,103 & 1 & 0,103 \\
\hline T2 & $\begin{array}{l}\text { Kurangnya alat } \\
\text { tranportasi umum }\end{array}$ & 0,106 & 3 & 0,317 \\
\hline T3 & $\begin{array}{l}\text { Kurangnya dukungan } \\
\text { Pemerintah Daerah }\end{array}$ & 0,106 & 2 & 0,212 \\
\hline T4 & $\begin{array}{l}\text { Minimnya petunjuk arah } \\
\text { menuju lokasi }\end{array}$ & 0,098 & 2 & 0,196 \\
\hline T5 & $\begin{array}{l}\text { Terjadi } \\
\text { bencana/gangguan alam }\end{array}$ & 0,106 & 2 & 0,212 \\
\hline \multicolumn{2}{|c|}{ Total } & 1,000 & & 2,179 \\
\hline
\end{tabular}

Total nilai tertimbang EFAS (External Factor Analysis Summary) key person sebesar 2,179 .

\subsubsection{Matriks SWOT}

Langkah selanjutnya adalah menyusun matriks SWOT guna menentukan alternative strategi. Matriks ini disusun oleh faktor-faktor kekuatan, kelemahan, peluang dan ancaman yang merupakan penyusun faktor-faktor strategis analisis internal dan eksternal. Penyusunan matriks SWOT dapat dilihat pada Tabel 4.13.

Tabel 4.15 Matriks SWOT (Strengths Weaknesses Opportunities Threaths)

\begin{tabular}{|c|c|c|}
\hline EKSTERNAL & $\begin{array}{ll}\text { Strengths }(\mathbf{S}) \\
1 . & \text { Letak yang Strategis. } \\
2 . & \text { Melihat proses } \\
& \text { pembuatan keris. } \\
\text { 3. } & \text { Pemandangan alam yang } \\
& \text { indah. } \\
4 . & \text { Keramahan masyarakat. } \\
5 . & \text { Terdapat bangunan } \\
& \text { bersejarah. }\end{array}$ & $\begin{array}{ll}\text { Weakness }(\mathbf{W}) \\
1 . & \begin{array}{l}\text { Pengrajin keris semakin } \\
\text { berkurang. }\end{array} \\
2 . & \begin{array}{l}\text { Kurangnya partisipasi } \\
\text { masyarakat. }\end{array} \\
3 . & \begin{array}{l}\text { Promosi belum } \\
\text { maksimal. }\end{array} \\
4 . & \begin{array}{l}\text { Kurang maksimalnya } \\
\text { toko souvenir. }\end{array} \\
5 . & \begin{array}{l}\text { Kurangnya tenaga kerja } \\
\text { professional dalam } \\
\text { pengelolaan objek } \\
\text { wisata. }\end{array} \\
\end{array}$ \\
\hline $\begin{array}{ll}\text { Opportunities }(\mathbf{O}) \\
1 . & \text { Melestarikan budaya jawa. } \\
2 . & \text { Menyerap tenaga kerja. } \\
3 . & \text { Pemanfaatan teknologi untuk media } \\
4 . & \text { promosi. } \\
\text { Kesan positif dari wisatawan yang } \\
\text { pernah berkunjung. } \\
\text { 5. } & \begin{array}{l}\text { Perluas segmen wisatawan dari } \\
\text { berbagai minat seperti fotografi, } \\
\text { pendidikan dan penelitian. }\end{array}\end{array}$ &  & $\begin{array}{ll}\text { WO } & \\
\text { 1. } & \text { Memperkenalkan dan } \\
& \text { menerangkan proses } \\
\text { pembuatan keris. } \\
\text { 2. } & \begin{array}{l}\text { Memanfaatkan media } \\
\text { social dalam }\end{array} \\
& \text { mempromosikan desa } \\
\text { wisata. } & \text { Mengadakan pelatihan } \\
\text { 3. } & \begin{array}{l}\text { Malam pengelolaan desa } \\
\text { wisata. }\end{array} \\
& \end{array}$ \\
\hline 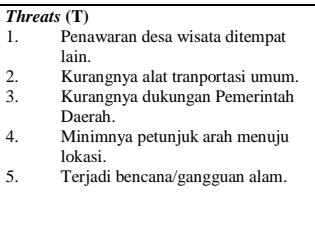 & $\begin{array}{cl}\text { ST } & \\
\text { 1. } & \begin{array}{l}\text { Mengadakan kerjasama } \\
\text { dengan objek pariwisata }\end{array} \\
\text { yang berdekatan. } \\
\text { 2. } & \begin{array}{l}\text { Menawarkan alat } \\
\text { transporasi alternatif dan }\end{array} \\
& \begin{array}{l}\text { petunjuk arah menuju } \\
\text { lokasi wisata. }\end{array} \\
\text { 3. } & \begin{array}{l}\text { Penyuluhan evakuasi } \\
\text { korban, seandainya }\end{array} \\
& \text { terjadi bencana alam di } \\
\text { lokasi wisata. }\end{array}$ & $\begin{array}{cl}\text { WT } & \\
\text { 1. } & \text { Meningkatkan partisipasi } \\
& \text { masyarakat dalam } \\
\text { pelayanan wisatawan. } \\
\text { 2. } & \text { Meningkatkan kualitas } \\
& \text { keunggulan objek wisata } \\
& \text { untuk mengatasi } \\
\text { 3. } & \text { persaingan pariwisata. } \\
\text { Memaksimalkan toko } \\
\text { souvenir untuk menjual } \\
\text { sebagian dari hasil } \\
\text { pengrajin. }\end{array}$ \\
\hline
\end{tabular}

Hasil dari matriks SWOT yang didapat dari perumusan strategi SO yang merupakan perpaduan dari faktor kekuatan dan peluang dengan alternatif yaitu meningkatkan pemasaran wisata, meningkatkan kualitas sumber daya manusia, memelihara mutu daya tarik wisata, menjaga kelestarian dan bangunan bersejarah.

Berikutnya strategi WO yang merupakan perpaduan dari faktor kelemahan dan peluang memberikan alternatif yaitu dengan memperkenalkan dan menerangkan proses pembuatan keris, memanfaatkan media social dalam mempromosikan desa wisata, mengadakan pelatihan dalam pengelolaan desa wisata.

Strategi ST yang merupakan perpaduan faktor kekuatan dan ancaman memberikan alternatif strategi dengan cara mengadakan kerjasama dengan objek pariwisata yang berdekatan, menawarkan alat transporasi alternatif dan petunjuk arah menuju lokasi wisata, penyuluhan evakuasi korban seandainya terjadi bencana alam di lokasi wisata.

Strategi WT yang merupakan strategi pertimbangan faktor kelemahan dan ancaman dengan cara meningkatkan partisipasi masyarakat dalam pelayanan wisatawan, meningkatkan kualitas keunggulan objek wisata untuk mengatasi persaingan pariwisata, memaksimalkan toko souvenir untuk menjual sebagian dari hasil pengrajin.

\subsubsection{Matriks Internal-Eksternal Pengunjung}

Analisis internal-eksternal dilakukan untuk mempertajam hasil evaluasi dan analisis yang telah dilakukan sebelumnya. Analisis ini akan menghasilkan matriks internal-eksternal yang berguna untuk mengetahui posisi Dusun Banyumurup saat ini sehingga dapat memberikan pilihan alternative strategi. Pemetaan posisi sangat penting bagi pemilihan alternatif strategi dalam pengembangan desa wisata. Berdasarkan skor rata-rata dari matriks IFAS dan EFAS maka dapat disusun matriks I-E (Internal Eksternal). Skor IFAS sebesar 2,5073 menggambarkan bahwa Dusun Banyumurup berada dalam kondisi internal rata-rata. Nilai EFAS sebesar 2,221 menggambarkan bahwa Dusun Banyumurup memiliki kemampuan yang sedang dalam memanfaatkan peluang maupun menghindari ancaman lingkungan eksternal. Penyusunan matriks internal-eksternal dapat dilihat pada gambar 4.2 berikut ini. 


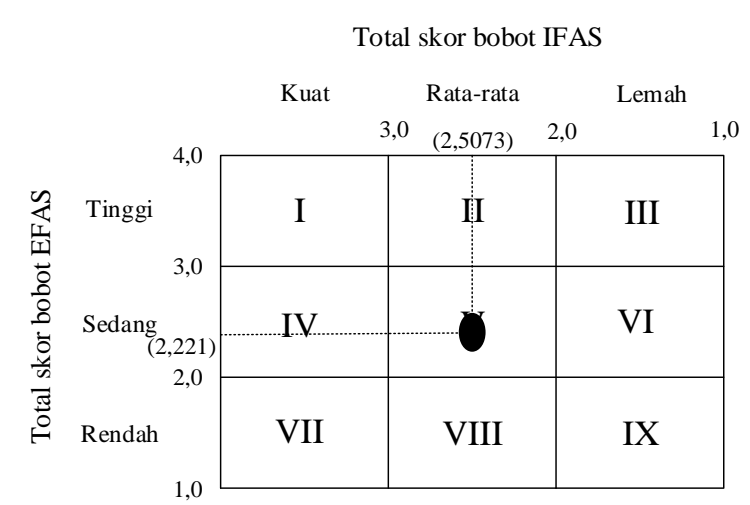

Gambar 4.2 Matriks Internal-Eksternal Dusun Banyumurup

Pemetaan terhadap masing-masing total skor dari faktor-faktor internal daneksternal menggambarkan posisi Dusun Banyumurup saat ini berada pada sel V dalam matriks IE. Oleh karena itu, strategi terbaik yang sebaiknya dilakukan adalah menjaga dan mempertahankan posisi yang selama ini sudah diraih. Kebijakan yang umum dari strategi ini adalah dengan melakukan penetrasi pasar dan mengembangkan produk. Artinya Dusun Banyumurup harus mempertahankan posisinya dengan terus mengembangkan produknya dan melakukan penetrasi ke ceruk pasar yang potensial dan selama ini belum tergarap, selain dengan tetap menjaga konsistensi dan kualitas produk.

\section{KESIMPULAN DAN SARAN}

\subsection{Kesimpulan}

Berdasarkan hasil pengolahan data dan hasil analisis yang mengacu dari tujuan penelitian dapat disimpulkan bahwa :

1. Berdasarkan hasil identifikasi potensi wisata yang dilakukan di Dusun Banyumurup, maka diperoleh daya tarik yang ada terdiri dari pemandangan alam, bangunan bersejarah dan sentra pengrajin keris.

2. Faktor internal yang dimiliki yaitu suasana khas pedesaan, melihat proses pembuatan keris, pemandangan alam yang indah, keramahan masyarakat, terdapat bangunan bersejarah. Sedangakan faktor eksternal yaitu melestarikan budaya Jawa, meyerap tenaga kerja, pemanfaatan teknologi untuk media promosi, kesan positif dari wisatawan yang pernah berkunjung, perluasan segmen wisatawan dari berbagai minat seperti fotografi, pendidikan atau penelitian.

3. Berdasarkan hasil matriks SWOT didapati strategi pembangunan desa wisata di Dusun Banyumurup sebagai berikut :

a. strategi SO yang merupakan perpaduan dari faktor kekuatan dan peluang dengan alternatif yaitu meningkatkan pemasaran wisata, meningkatkan kualitas sumber daya manusia, memelihara mutu daya tarik wisata, menjaga kelestarian dan bangunan bersejarah.

b. strategi WO yang merupakan perpaduan dari faktor kelemahan dan peluang memberikan alternatif yaitu dengan memperkenalkan dan menerangkan proses pembuatan keris, memanfaatkan media social dalam mempromosikan desa wisata, mengadakan pelatihan dalam pengelolaan desa wisata.

c. Strategi ST yang merupakan perpaduan faktor kekuatan dan ancaman memberikan alternatif strategi dengan cara mengadakan kerjasama dengan objek pariwisata yang berdekatan, menawarkan alat transporasi alternatif dan petunjuk arah menuju lokasi wisata, penyuluhan evakuasi korban seandainya terjadi bencana alam di lokasi wisata.

d. Strategi WT yang merupakan strategi pertimbangan faktor kelemahan dan ancaman dengan cara meningkatkan partisipasi masyarakat dalam pelayanan wisatawan, meningkatkan kualitas keunggulan objek wisata untuk mengatasi persaingan pariwisata, memaksimalkan toko souvenir untuk menjual sebagian dari hasil pengrajin.

\subsection{Saran}

Dengan adanya promosi dan pengelolaan desa wisata yang tepat diharapkan mampu 
meningkatkan jumlah kunjungan wisatawan. Dan warga Dusun Banyumurup diharapkan tetap menjaga dan mempertahankan potensi yang dimiliki seperti keindahan alam, sentra pengrajin keris dan bangunan bersejarah sebagai objek wisata tanpa banyak melakukan perubahan yang dapat merusak potensi yang ada.

\section{DAFTAR PUSTAKA}

Darsiharjo, 2016, Strategi Pengembangan Wisata Minat Khusus Arum Jeram di Sungai Palayang. Jurnal Fakultas Pendidikan Ilmu Pengetahuan Sosial UPI. Bandung

Desa Girirejo, 2016 , Peta Banyumurup, Pemerintahdesagirirejo.blogspot.co.i d, diakses 3 Juni 2017.

Dharmawan, 2014, Strategi Pengembangan Desa Wisata di Desa Belimbing Kecamatan Pupuan Kabupaten Tabanan. Jurnal Studi Agribisnis, Fakultas Pertanian, Universitas Udaya. Bali.

Dodi Widiyanto, 2008, Pengembangan Pariwisata Perdesaan (Suatu Usulan Strategi Bagi Desa Wisata Ketingan). Jurnal Program Studi Pembangunan Wilayah Fakultas Geografi UGM. Yogyakarta.

Elyarni Reca, 2016, Analisis SWOT Terhadap Strategi Pemasaran Layanan SAP Express pada PT. SAP. Jurnal Teknik Industri Universitas Indraprasta PGRI. Jakarta.

Kusnanto , 2015, Makam Banyumurup Imogiri Bantul. Kusnantokarasan.com /makam-banyusumurup-imogiribantul/, diakses: 11 Juni 2017.

Nur'aini, F., 2016. Teknik Analisis SWOT. Quadrant, Yogyakarta.

Prihtiyani, E., 2010,Persinggahan Sultan Agung, nasional.kompas.com/read/2010

diakses: 9 Juni 2017.

Rachmat, H.R., 2008, Analisis Strategi Pemasaran Pariwisata Pantai Parangtritis Pasca Gempa Bumi dan Tsunami di Kabupaten Bantul, Program Studi Manajemen Bisnis dan Ekonomi Perikanan-Kelautan, ITB, Bogor.
Rangkuti, F., 2005. Analisis SWOT Teknik Membedah Kasus Bisnis. PT Gramedia Pustaka Utama, Jakarta.

Selvia Maryam, 2011, Pendekatan SWOT Dalam Pengembangan Objek Wisata Kampoeng Djowo Sekatul, Kabupaten Kendal. 